\title{
Variation of Seed Dosage on Corn Crop Production Components
}

\author{
Rafael De Graaf Corrêa ${ }^{1}$, Carlos Eduardo Angeli Furlani ${ }^{1}$, Cristiano Zerbato ${ }^{1}$, Danilo Tedesco de Oliveira ${ }^{1}$ \\ $\&$ Mailson Freire de Oliveira ${ }^{1}$ \\ ${ }^{1}$ Faculty of Agrarian and Veterinary Sciences, Paulista State University, Jaboticabal, Brazil \\ Correspondence: Rafael De Graaf Corrêa, Faculty of Agrarian and Veterinary Sciences, Paulista State University, \\ Jaboticabal, SP, Brazil. Tel: 55-14-996-720-095. E-mail: rafadegraaf@gmail.com
}

\author{
Received: May 7, $2018 \quad$ Accepted: June 11, $2018 \quad$ Online Published: July 15, 2018 \\ doi:10.5539/jas.v10n8p296 URL: https://doi.org/10.5539/jas.v10n8p296
}

\begin{abstract}
The variation in population density in a corn crop can positively, negatively or neutrally affects plant productivity depending on the productive potential of the area. The aim of this work was to evaluate the effects of the variation in corn seed dosage on crop yield, and define from which percentage of variation the productivity of the sown line is affected negatively. The experiment was installed at FCAV-UNESP, in Jaboticabal (SP), Brazil. Twelve variations on plant population were evaluated, ranging from $-27 \%$ to $27 \%$, varying with a frequency of $4.5 \%$. The morphological and productive characteristics of each treatment were evaluated through regression analysis. Each $1 \%$ of negative variation on seed dosage was lost $1.06 \%$ in corn yield. Positive variations, however, presented changes that were 0 to $-2.59 \%$. Negative variations on seed dosage reduced corn productivity by up to $28 \%$. The positive variation affects the productivity of the crop in a less accentuated way, with a reduction in productivity that reaches $2.59 \%$ in the largest variations and may even cause positive productivity results depending on the maximum potential of the area.
\end{abstract}

Keywords: plant population, seeding population, Zea mays L.

\section{Introduction}

Plant density is a determinant factor in the productivity of several crops, especially in corn, which does not have the plasticity that other crops should compensate for the absence of plants (Silva et al., 2016). When in a population inferior to to the recommended one, corn produces less grains per area, failing to take advantage of the resources available on the soil, already in superior population to the recommended one, there is an intra-specific competition by photoassimilates, especially in the flowering stage of the crop (Calonego et al., 2011).

The variation in population density in a corn crop can positively, negatively or neutrally affects plant productivity depending on the productive potential of the area (Assefa et al., 2016). It can occur intentionally to meet technical recommendations, or in a natural way, through failures in the sowing process. According to Cortez et al. (2016) the speed of sowing affects the amount of seed distributed in the rows of the sowing machine. However, in addition to sowing speed, there are other factors that contribute to the existence of variations in seed dosage throughout the operation, but which, unlike the machine's travel speed, cannot be controlled to avoid operating failures, such as curve seeding errors.

When operating in curved trajectories there is a variability on the number of seeds distributed between the rows of the seedlings, and larger seeders combined with the closed curves generate greater variability in the seed dosage, and consequently in the plant population. Similar factor occurs in operations with sprayers. Luck et al. (2011) concluded that performing curves in the sprayer operation causes a substantial portion of the field to receive dosages that vary by more than $10 \%$ relative to the target rate depending on the radius of curvature.

However, even though it is a problem inherent to the sowing operation, little is known about the effects of the variation in the density of corn plants caused by this operation. Although it is a determining factor for crop productivity, there are no studies that show the effects of variation on seed dosage with a focus on modern hybrids, so there are no reasons that motivate producers and the agricultural machinery industry to invest in technologies to remedy this problem, affecting productivity of corn crops in national scale.

This work is based on the hypothesis that variations on seed dosage have negative effects on corn crop productivity. Based on the information presented previously, the aim was to evaluate the effects of the variation 
on seed dosage of the corn hybrid 2B710 PW on the components of its production components, to define from which percentage of variation the productivity of the seeded line is affected and test the potential of the methodology used in the work to define the maximum number of plants that the area can support.

\section{Method}

The experiment was carried out at the Campus of Research and Extension (FEPE) of the Faculty of Agrarian and Veterinary Sciences, São Paulo State University, at the Campus of Jaboticabal (SP), located near the coordinates $21^{\circ} 14^{\prime} \mathrm{S}$ and $48^{\circ} 16^{\prime} \mathrm{W}$, with average elevation of the area of 568 meters and average slope of $4 \%$, where the relief is defined as smooth wavy.

The climate classification of the Clima Aw (subtropical) region, according to the classification of Köppen adapted by Alvares et al. (2013). The soilof the area is classified as typical Eutrophicric red, A moderate, clayey texture and smooth undulating relief (Table 1) (EMBRAPA, 2013).

Table 1. Initial soil properties in the layers of $0.00-0.10,0.10-0.20$ and $0.20-0.30 \mathrm{~m}$

\begin{tabular}{|c|c|c|c|c|c|c|c|c|c|c|}
\hline \multirow{2}{*}{ Depth (m) } & \multirow{2}{*}{$\mathrm{PH}$} & \multirow{2}{*}{$\mathrm{Al}$} & \multirow{2}{*}{$\mathrm{H}+\mathrm{Al}$} & \multicolumn{4}{|c|}{ Macronutrients } & \multicolumn{3}{|c|}{ Complementar results } \\
\hline & & & & $\mathrm{P}$ & $\mathrm{K}$ & $\mathrm{Ca}$ & $\mathrm{Mg}$ & SB & CTC & $\mathrm{V} \%$ \\
\hline $0.00-0.10$ & 5.6 & 0.0 & 26 & 65 & 5.5 & 53 & 20 & 78,5 & 104,8 & 75 \\
\hline $0.10-0.20$ & 5.5 & 0.0 & 31 & 59 & 4.3 & 32 & 13 & 49,3 & 80,4 & 61 \\
\hline $0.20-0.30$ & 5.3 & 0.0 & 33 & 34 & 3.6 & 30 & 11 & 44,6 & 78,0 & 57 \\
\hline
\end{tabular}

Note. PH: determined in solution of calcium chloride; Al: extraction by solution of potassium chloride and determination by titulometry; $\mathrm{H}+\mathrm{Al}$ : determined in SMP buffer solution at $\mathrm{pH} 7.5$; $\mathrm{P}$ (res): ion exchange resin extraction; $\mathrm{K}, \mathrm{Ca}, \mathrm{Mg}$ : extraction and determination by spectroscop; $\mathrm{SB}$ : sum of base; CTC: cation exchange capacity; V: soil base saturation (SB/CTC ratio).

It is observed at Figure 1, regarding the meteorological data in the period of the experiment, that the temperature remained stable throughout the months and within the ideal range for the development of the culture. Rainfall, however, was lower than evapotranspiration at the beginning of the reproductive period and at the end of the vegetative period, which impaired the productive potential of the crop due to the lower water availability in this period.

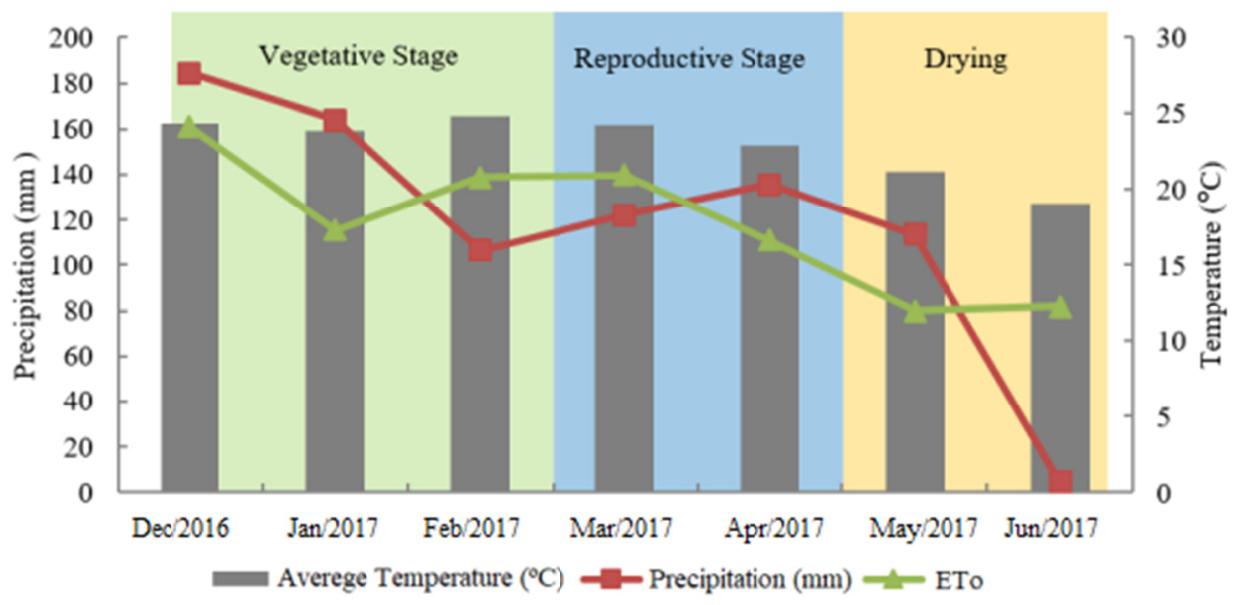

Figure 1. Meteorological data of the experimental period

\subsection{Experimental Design}

A randomized complete block design was used, with 12 treatments and 4 replications, totalizing 48 experimental plots. Twelve variations in the plant population were used, ranging from $-27 \%$ to $27 \%$ varying with a frequency of $4.5 \%$, given by (Equation 1) simulating the errors of a seeder of 12 rows spaced at 0.9 meters of each other, sowing 67,777 seeds ha- ${ }^{1}$ in a curve with a radius of 20 meters, which can be considered a closed curve. 


$$
\mathrm{PV}=100-\left[\frac{2 \pi \cdot(\mathrm{R} \pm \mathrm{D})}{2 \pi \mathrm{R}}\right] \times 100
$$

Where, $\mathrm{R}=$ radius of curvature; $\mathrm{D}=$ Line spacing $\pm \mathrm{R}$; and $\mathrm{PV}=$ Percentage of variation in seed dosage in relation to target rate.

\subsection{Informations About the Experiment}

The experiment was implemented in a no-tillage system on corn straw in the 2016/2017 crop. For the control of weeds, 4 liters ha ${ }^{-1}$ of RoundUp Glyphosate and 2 liters ha ${ }^{-1}$ of Atrasine Nortox 500 SC were previously applied to the experiment. Along the field, corn was sown to be used as a border for the plots with the aid of a seeder-fertilizer. However, within the blocks the seedlings stopped distributing seeds and distributed only the fertilizer with a volume of $350 \mathrm{~kg} \mathrm{ha}^{-1}$ of NPK (N: urea, P: triple super phosphate, and K: potassium chloride) in formulation 8-28-16.

Seeding of the plots was done manually, with glyphosate tolerant 2B710 PW corn hybrid with three insecticidal proteins and an early trait with recommended final population for the region of 60,000 plants per hectare with germination, purity and survival rates $95 \%, 98 \%$, and $95 \%$ respectively. It was sought by means of the use of wooden jigs with demarcations of the positioning of the seeds, in each treatment to reach the population defined by the variations presented on Table 2. Each plot had a seeding line spaced 0.9 meters from the other and with length of seven meters. The cover fertilization occurred when the crop reached the vegetative stage V4, and 350 $\mathrm{kg} \mathrm{ha}^{-1}$ of urea (157 kg ha ${ }^{-1}$ of nitrogen) was applied in the total area with distributor to the haul coupled to the tractor.

Table 2. Experimental treatments

\begin{tabular}{llll}
\hline Treatments & Variation $(\%)$ & Seeds $^{*}\left(\mathrm{ha}^{-1}\right)$ & Plants $^{* *}\left(\mathrm{ha}^{-1}\right)$ \\
\hline 1 & -27.5 & 49477.94 & 43787.97 \\
2 & -22.5 & 52527.95 & 46487.23 \\
3 & -18.0 & 55577.96 & 49186.49 \\
4 & -13.5 & 58627.97 & 51885.75 \\
5 & -9.0 & 61677.98 & 54585.01 \\
6 & -4.5 & 64727.99 & 57284.27 \\
7 & 4.5 & 70828.01 & 62682.78 \\
8 & 9.0 & 73878.02 & 65382.04 \\
9 & 13.5 & 76928.03 & 68081.30 \\
10 & 18.0 & 79978.04 & 70780.56 \\
11 & 22.5 & 83028.05 & 73479.82 \\
12 & 27 & 86078.06 & 76179.08 \\
\hline
\end{tabular}

Note. ${ }^{*}$ Initial seed booth. ${ }^{* *}$ Final population of plants based on the germination, survival and purity indexes described in seed information of the seeded hybrid.

\subsection{Sampling Procedures}

On reaching the first reproductive stage, the parameters were evaluated in five plants of each plot:

$>$ Height of plants: for this evaluation was used a ruler graduated with an accuracy of one $\mathrm{cm}$, positioned from the soil until the insertion of the flag leaf.

$>$ Stem diameter: a pachymeter positioned at five centimeters from the ground was used and measured the largest axis of the stem to control the samplings.

$>$ Ear numbers: five plants were randomly selected in each plot and the number of ears in the plant checked.

$>$ At the end of the reproductive stage, when the grain moisture was close to $18 \%$, the ears of the central five meters of each plot were collected and evaluated:

> Length of ears: five ears were collected and measured lengthwise from one end to the other using a graduated ruler with a precision of one $\mathrm{cm}$.

Spindle diameter: the diameter of five ears was measured with the aid of a precision caliper of one $\mathrm{mm}$, positioning it in the center of the spigot. 
$>$ Diameters of sips: the diameters of five sips were measured with the aid of a precision caliper of one mm placing it in the center of the cob.

- Grain mass: a sample of 1000 grains per plot was counted to perform the weighing of the same was used a scale of precision of one $\mathrm{g}$.

$>$ Productivity: all the ears of the central five meters of the plots were harvested, later they were trodden by means of electric threshing machine, and the humidity of the grains was measured through a humidity sensor. The harvested grains were weighed and the results corrected for the wet basis of $13 \%$.

After the evaluations, the data were tabulated and the weight of the samples of the plots was extrapolated to $\mathrm{kg}$ $\mathrm{ha}^{-1}$, facilitating to understand the effects of the variation in the plant population between the rows of the planter.

The results of the tested variables were submitted to the $\mathrm{F}$ test and to the regression analysis at $5 \%$ of significance level to verify the behavior of the samples as a function of the percentage of variation in the plant population, using the AgroEstat statistical software (Barbosa \& Maldonado, 2014). After the regression analysis of productivity, was performed the equation obtained through it was used to estimate the change in productivity of each $1 \%$ variation in relation to the $0 \%$ variation.

\section{Results and Discussion}

According to the $\mathrm{F}$ test for the regressions no significant results were found for the variable number of ears, which did not differ between treatments. In the regression analysis for the plant height variable the polynomial regression model that best fit and explained the results of the variable was the quadratic, with coefficient of determination $\left(\mathrm{R}^{2}\right)$ of 0.75 .

It is observed in Figure 2 that the data behaved in a way that the negative variation on the population density (when the density was lower than the desired one) the plants were higher, decreasing with the increase of the population until the point of minimum. Balbinot and Fleck (2005) founded hat increasing plant density resulted in increased plant height and reduced plant stem diameter, among other things. The height stabilized around $9 \%$, which can be considered the minimum point of the graph. From this percentage, it was observed that the height of the plants began to increase again, demonstrating that the negative variation in population density causes growth in plant height as well as the positive variations from $9 \%$.

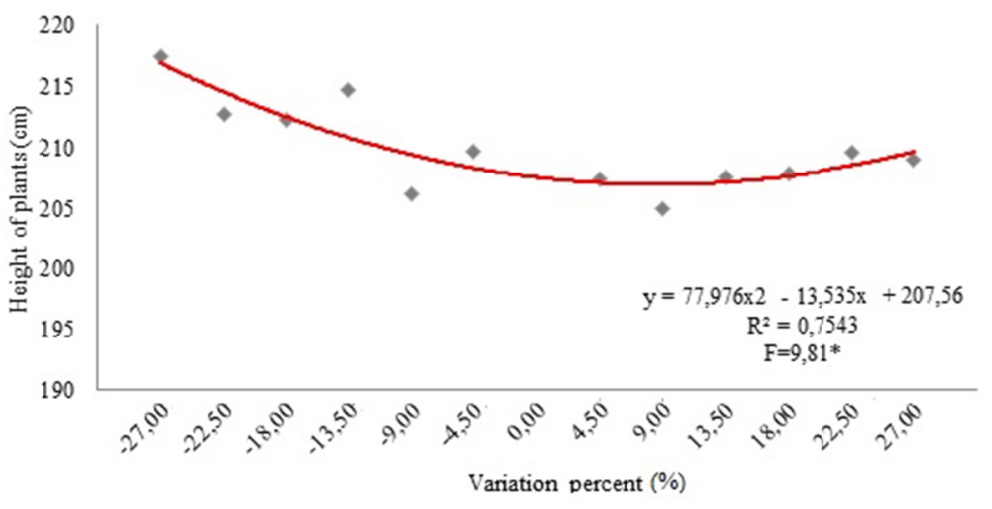

Figure 2. Regression analysis for plant height variability

The inverse effect that was predicted by other authors in the treatments where the population density was inferior due to the negative variation on the seed dosage can be explained by the fact that the plants have greater availability of water and nutrients for its development, and therefore grow more than in the treatments of the desired population. What distinguishes the increase in height of plants explained above the increase in height of plants caused by the intra-specific competition founded in more densified crops is the fact that the stem plant diameter in question is also higher than those founded in the other treatments. Intraspecific competition of corn plants is characterized by the fact that they have smaller stem diameter and higher plants than treatments where the phenomenon was not diagnosed, which may have occurred from the $9 \%$ variation.

The polynomial regression analysis for the stem diameter variable was fitted to the linear model, with $\mathrm{R}^{2}=0.75$. It is observed at Figure 3 that the plant stem diameters decreased with increasing variation in seed dosage, 
corroborating the results reported by Balbinot and Fleck (2005). These results combined with the results of plant height reinforce the theory that in the populations with variation greater than $11 \%$ the plants began to compete for water, nutrient and luminosity, because plants of the same species, when in high densification, have mechanisms that prevent their root growth and this causes less absorption of nutrients.

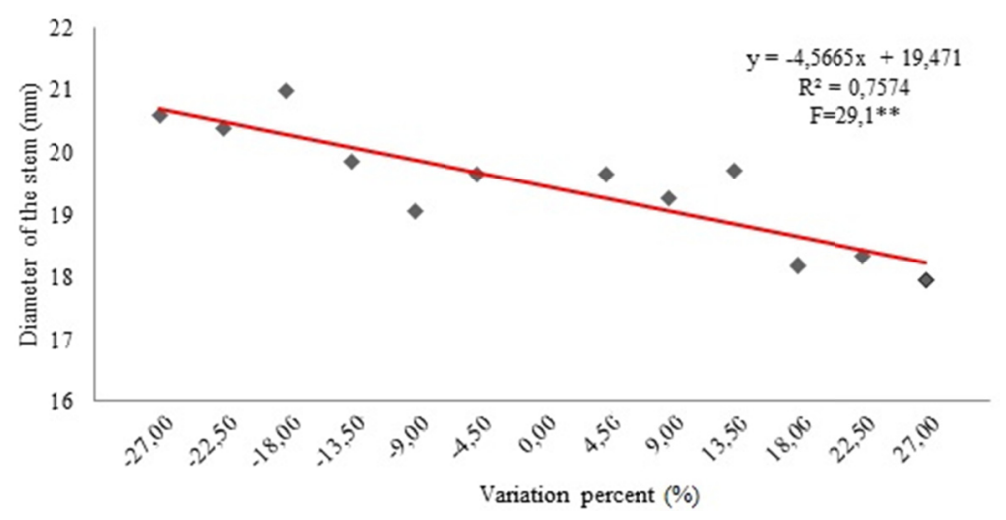

Figure 3. Regression analysis for stem diameter variable

In the polynomial regression analysis of the ear diameter variable, the model that fitted most appropriately the data was linear, with $\mathrm{R}^{2}=0.79$. In the less densified treatments the plants produced ears of larger diameter (Figure 4), demonstrating that the behavior of the ear diameter variable is inversely proportional to the population growth. The higher availability of nutrients per plant that occurs in treatments with lower population density is an important factor and may explain the results obtained. Thicker ears indicate larger grains, and consequently higher mass.

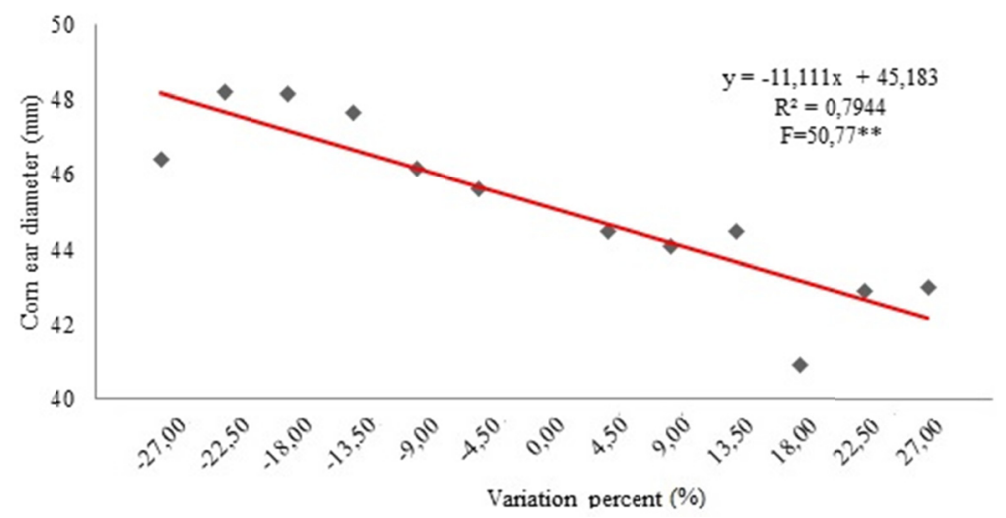

Figure 4. Regression analysis for the variable ear diameter

In the polynomial regression analysis of the ear length variable, the model that fitted the data more adequately was linear, with $\mathrm{R}^{2}=0.87$. Figure 5 shows that at lower population densities the ears were larger, decreasing with the increase of the number of plants. Ear length is generally affected by local water availability and others stresses facts, thus, in less densified treatments the water ratio per plant is higher, and consequently, in water stress conditions these treatments stand out. According to Bratchvogel et al. (2009) under conditions of water stress, the corn plant tends to abort the filling of the grain of the tips of the ear, making them shorter. 


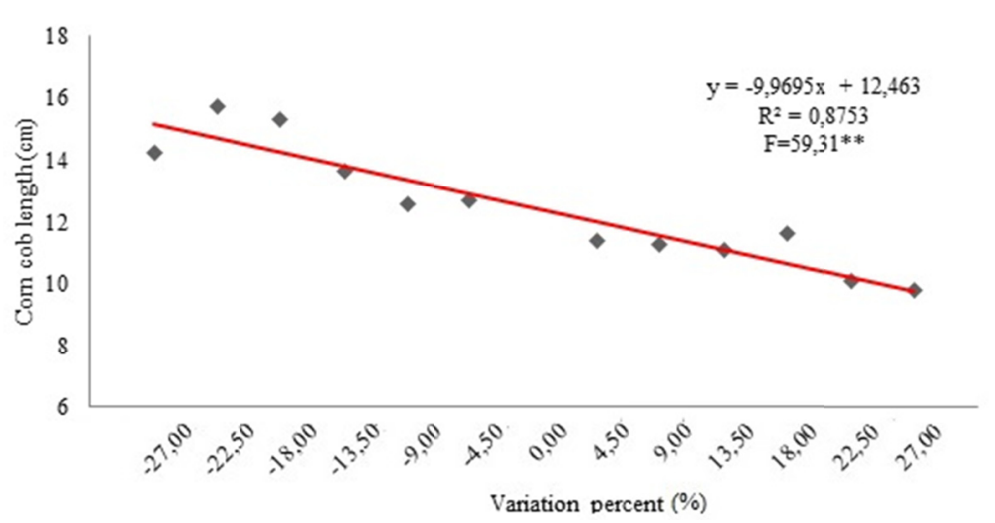

Figure 5. Regression analysis for the ear length variable

The model that best fits the results of the variable diameter of the cob was quadratic, with coefficient of determination of 0.89 . Figure 6 shows that the lower part of the data curve starts close to the $9 \%$ variation, and slowly rises again after $13.5 \%$ variation. This means that the treatments with smaller diameter of cob were in the range of 9 to $13.5 \%$. According to Marchão et al. (2005), the diameter of the cob is one of the productive characteristics of the corn that undergoes changes in its diameter as a function of the population density.

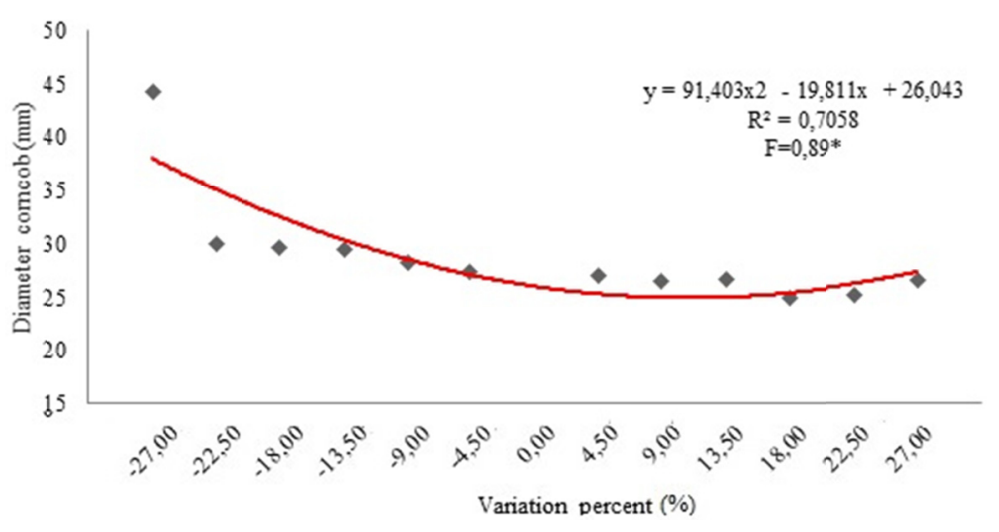

Figure 6. Regression analysis for the variable diameter of the cob

The polynomial regression for the 1000 grain mass variable was adjusted to the linear model with $\mathrm{R}^{2}=0.78$. As can be seen in Figure 7, the grain mass decreased with the population increase. This variable can be related to the diameter of the ears, since thicker ears have larger grains, and consequently, they have greater mass. In general, the diameter of the ears may have been the factor that influenced the behavior of the grain mass. 


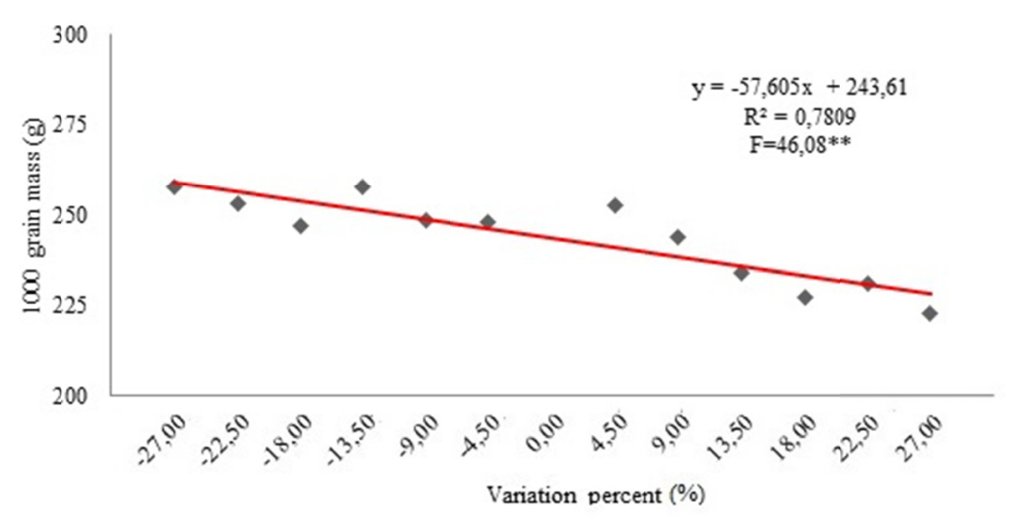

Figure 7. Regression analysis for the variable 1000 grain mass

The polynomial regression for the productivity variable (Figure 8 ) was adjusted to the quadratic model, with a coefficient of determination of 0.71 . It is observed in Figure 8 , that the productivity data behaved forming a curve that reaches the maximum productivity point at the $11 \%$ variation percentage, confronting the hypothesis of the work, which is that the variation on the seed dosage has negative effects on the productivity of the crop. This result may have occurred because apparently the maximum population potential was subjugated, and it was considered that the ideal population density was only $60,000 \mathrm{ha}^{-1}$ plants, the results show that the maximum potential would be approximately $66,000 \mathrm{ha}^{-1}$ plants. However, this result reinforces the assertion made by Assefa et al. (2016) that variations on plant density can positively or negatively affect crop yield, and in this case, both positive and negative responses were found, depending on the percentage of variation studied.

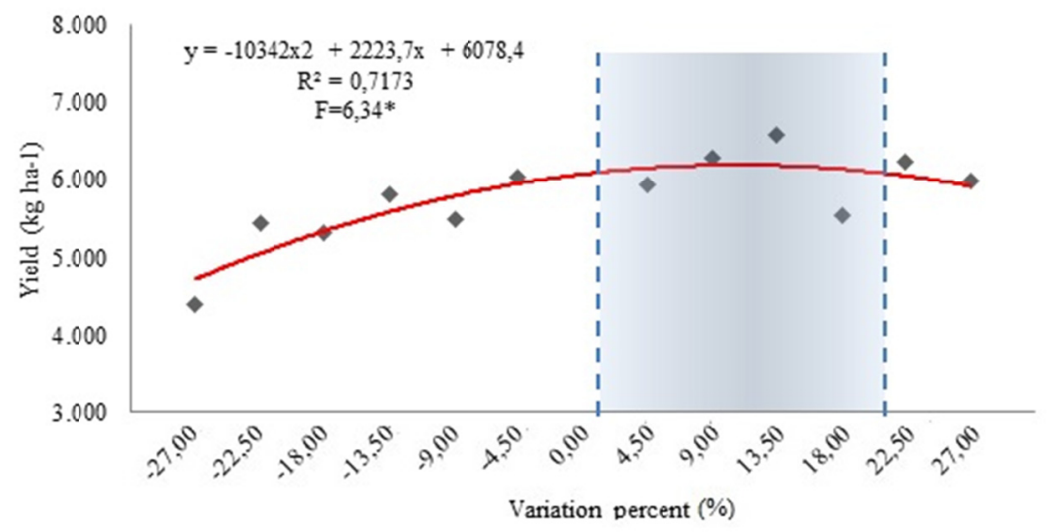

Figure 8. Regression analysis for the yield variable

However, in general, it was verified that the variations that comprise the range of 0 to $22 \%$ do not negatively affect productivity when compared to productivity with $0 \%$ variation, and the percentage that caused the highest productivity was $11 \%$, probably the one that understood the maximum productive potential of the corn hybrid studied in the area where the experiment was carried out. From $22 \%$, productivity became less than $0 \%$, because the competition between plants, which can be predicted in previous variables, and according to Calonego et al. (2011) affects the crop mainly in the productive phase.

On the other hand, the negative variations, although they showed results in the previous variables indicating that the plants would be more productive, responded contrary to the expected one, since even the plants producing more individually, this increase on the production was not enough to compensate the smaller number of individuals present in the treatment. Farinelli et al. (2012) observed the same behavior varying populations from 60,000 to $80,000 \mathrm{ha}^{-1}$ plants in a corn crop.

In Figure 9 we verified the polynomial regression analysis for the percentage of change in productivity as a function of the variation in the dosage. To create the graphs, the regression equation of Figure 11 was 
decomposed and the productivities between -27 and $27 \%$ were calculated, with a frequency of $1 \%$, and then the percentages of productivity variability were calculated based on productivity of $0 \%$ variation in seed dosage. The model that best fit the data was the cubic, with coefficient of determination of 0.99 .

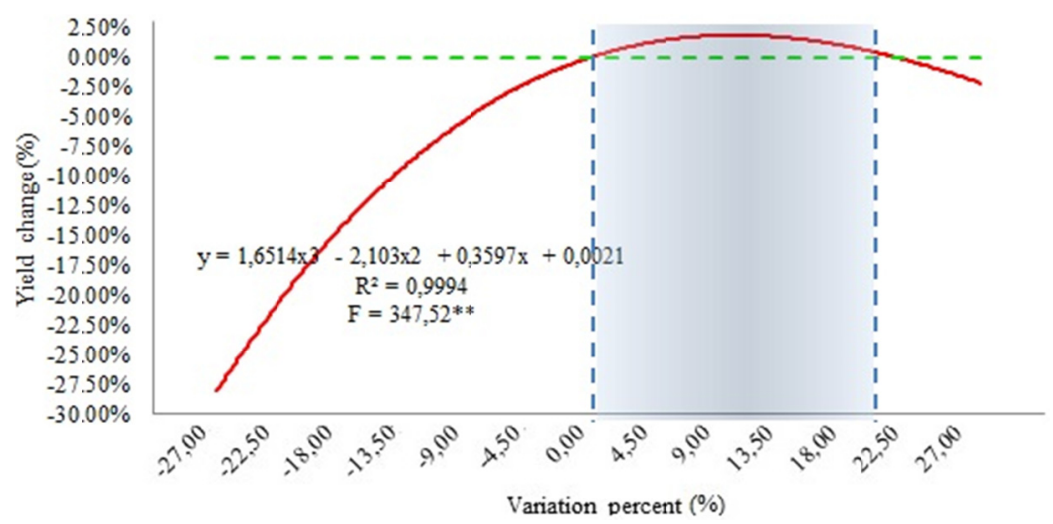

Figure 9. Regression analysis for the percentage change in productivity

Negative variations in seed dosage caused changes ranging from -0.38 to $-28.67 \%$ in crop yield, and every $1 \%$ negative variation in seed dosage lost $1.06 \%$ in yield, or in the case with productivity in the $0 \%$ variation being $6078.4 \mathrm{~kg} \mathrm{ha}^{-1}, 64.54 \mathrm{~kg}$ are lost. The positive variations, however, presented changes that were 0 to $-2.59 \%$, bringing maximum gains of $1.93 \%$ in the productivity when reaching the maximum point that was the variation of $11 \%$ in the dosage of seeds, and beginning to decay thereafter.

The results founded in this experiment are because the population density was subjugated, however, it was possible to define through the treatments the maximum potential that the area supports of this hybrid. If the maximum potential of the area had been explored, that is, if the desired final population had been $66,000 \mathrm{ha}^{-1}$ plants, all variations would have negative productivity results, with negative variations always more damaging to productivity than variations positive results in seed dosage. According to some authors, small increases in plant density increase crop productivity to a point where it stabilizes and begins to decrease slowly due to competition of plants at densities that exceed the potential of the area (Tollenaar \& Wu, 1999; Ciampitti \& Vyn, 2012).

\section{Conclusions}

The variation on seed dosage caused negative and positive effects to corn hybrid productivity, depending on the variation studied. Negative variation on seed dosage reduces corn hybrid productivity by up to $28 \%$ and any negative variance should not be tolerated. On the other hand, the positive variation affects the productivity of the crop in a less marked way, with a reduction in productivity that reaches $2.59 \%$ in the largest variations. The methodology used was adequate to determine the density of corn hybrids that brings higher productivity, being an alternative for the creation of maps of corn seed application at variable rates.

\section{References}

Alvares, C. A., Stape, J. L., Sentelhas, P. C., Moraes Gonçalves, J. L., \& Sparovek, G. (2013). Köppen’s climate classification map for Brazil. Meteorologische Zeitschrift, 22(6), 711-728. https://doi.org/10.1127/09412948/2013/0507

Assefa, Y. P. V., Vara Prasad, P., Carter, M., Hinds, G., Bhalla, R., Schon, M., ... Ciampitti, I. A. (2016). Yield Responses to Planting Density for US Modern Corn Hybrids: A Synthesis-Analysis. Crop Sci., 56, 2802-2817. https://doi.org/10.2135/cropsci2016.04.0215

Balbinot Jr., A. A., Fleck, N. G. (2005). Competitividade de dois genótipos de milho (Zea mays) com plantas daninhas sob diferentes espaçamentos entre fileiras. Revista Planta Daninha, 23(3), 415-421. https://doi.org/10.1590/S0100-83582005000300004

Barbosa, J. C., \& Maldonado Jr., W. (2014). Sistema para Análises Estatísticas de Ensaios Agronômicos (Versão 1.1.0.712). AgroEstat. 
Brachtvogel, E. L., Pereira, R. S., Cruz, S. C. S., \& Bicudo, J. S. (2009). Densidades populacionais de milho em arranjos espaciais convencional e eqüidistante entre plantas. Ciência Rural, 39(8), 2334-2339. https://doi.org/10.1590/S0103-84782009005000193

Calonego, J. C., Poleto, L. C., Domingues, F. N., \& Tiritan, C. S. (2011). Produtividade e crescimento de milho em diferentes arranjos de plantas. Agrarian, 4, 84-90. https://doi.org/10.30612/agrarian.v4i12.699

Ciampitti, I. A., \& Vyn, T. J. (2012). Physiological perspective of changes over time in maize grain yield dependency on nitrogen uptake and associated nitrogen efficiencies: A review. Field Crops Res., 133, 48-67. https://doi.org/10.1016/j.fcr.2012.03.008

Cortez, J. W., Chaves, R. G., Orlando, R. C., Souza, C., \& Souza, P. H. D. (2016). Penetration resistance and agronomic characteristics of soybean affected by soil management and sowing speed systems. Engenharia Agricola, 36(4), 664672. https://doi.org/10.1590/1809-4430-Eng.Agric.v36n4p664-672/2016

EMBRAPA (Empresa Brasileira de Pesquisa Agropecuária). (2013). Sistema Brasileiro de Classificação de Solos (3rd ed., p. 353). Brasília. EMBRAPA.

Farinelli, R., Penariol, F. G., \& Fornasieri Filho, D. (2012). Características agronômicas e produtividade de cultivares de milho em diferentes espaçamentos entre linhas e densidades populacionais. Cientifica, 40(1), 21-27. https://doi.org/10.15361/1984-5529.2012v40n1p21+-+27

Luck, J. D., Pitla, S. K., Zandonadi, R. S., Sama, M. P., \& Shearer, S. A. (2011). Estimating off-rate pesticide application errors resulting from agricultural sprayer turning movements. Precision Agriculture, 12(4), 534-545. https://doi.org/10.1007/s11119-010-9199-9

Marchão, R. L., Brasil, E. M., Guimarães, C. M., \& Gomes, J. A. (2005). Densidade de plantas e características agronômicas de híbridos de milho sob espaçamento reduzido entre linhas. Pesquisa Agropecuária Tropical, 35(2), 93-101.

Silva, D. H. R., Meneghello, G. E., Oliveira, S., Cavalcante, J. A., \& Tunes, L. M. (2016). População de plantas e desempenho produtivo de híbridos de milho oriundos de sementes com diferentes níveis de vigor. Revista Verde de Agroecologia e Desenvolvimento Sustentável, 11(2), 1. https://doi.org/10.18378/rvads. v11i2.4173

Tollenaar, M., \& Wu, J. (1999). Yield improvement in temperate maize is attributable to greater stress tolerance. Crop Sci., 39, 1597-1604. https://doi.org/10.2135/cropsci1999.3961597x

\section{Copyrights}

Copyright for this article is retained by the author (s), with first publication rights granted to the journal.

This is an open-access article distributed under the terms and conditions of the Creative Commons Attribution license (http://creativecommons.org/licenses/by/4.0/). 